This item was submitted to Loughborough's Research Repository by the author.

Items in Figshare are protected by copyright, with all rights reserved, unless otherwise indicated.

\title{
Using conversation analysis in feminist and critical research
}

PLEASE CITE THE PUBLISHED VERSION

http://dx.doi.org/10.1111/j.1751-9004.2007.00049.x

PUBLISHER

Wiley (@ The Authors)

VERSION

AM (Accepted Manuscript)

LICENCE

CC BY-NC-ND 4.0

REPOSITORY RECORD

Wilkinson, Susan J., and Celia Kitzinger. 2019. "Using Conversation Analysis in Feminist and Critical Research". figshare. https://hdl.handle.net/2134/15568. 
This item was submitted to Loughborough's Institutional Repository (https://dspace.lboro.ac.uk/) by the author and is made available under the following Creative Commons Licence conditions.

\section{creative
commons}

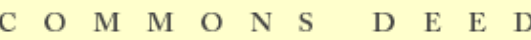

Attribution-NonCommercial-NoDerivs 2.5

You are free:

- to copy, distribute, display, and perform the work

Under the following conditions:

Attribution. You must attribute the work in the manner specified b the author or licensor.

Noncommercial. You may not use this work for commercial purposes.

No Derivative Works. You may not alter, transform, or build upon this work.

- For any reuse or distribution, you must make clear to others the license terms of this work.

- Any of these conditions can be waived if you get permission from the copyright holder.

Your fair use and other rights are in no way affected by the above.

This is a human-readable summary of the Leqal Code (the full license).

\section{Disclaimer 만}

For the full text of this licence, please go to: http://creativecommons.org/licenses/by-nc-nd/2.5/ 
Wilkinson, S. and Kitzinger, C. (2008) Using conversation analysis in feminist and critical research. Social and Personality Psychology Compass, 2(2): 555-573.

Using Conversation Analysis in Feminist and Critical Research

Sue Wilkinson (Loughborough University, UK)

and Celia Kitzinger (University of York, UK)

Sue Wilkinson (Corresponding author)

Department of Social Sciences

Loughborough University

Loughborough

Leicestershire LE11 3TU, UK

E-mail: S.Wilkinson@lboro.ac.uk

\section{Celia Kitzinger}

Department of Sociology

University of York

Heslington

York YO10 5DD, UK

E-mail: cck1@york.ac.uk 


\begin{abstract}
Conversation analysis - the study of talk-in-interaction - is proving a valuable tool for politically-engaged inquiry and social critique. This article illustrates the use of conversation analysis in feminist and critical research, drawing on a range of empirical studies. After introducing conversation analysis - its theoretical assumptions, methodological practices, and empirical findings - it highlights projects based on two key conversation analytic domains: turn-taking and turn-design, and sequence organization and preference structure. The final section examines the key contributions of conversation analysis to feminist and critical work in the areas of categories and gender; LGBT issues; women's labour; and the politics, ethics and design of the research process.
\end{abstract}


Using Conversation Analysis in Feminist and Critical Research

Sue Wilkinson and Celia Kitzinger

One of the most exciting contemporary developments in the field of conversation analysis (CA) is its use in feminist and other critical work. The key empirical discoveries of CA e.g. turn-taking and turn design, sequence organization and preference structure - are increasingly used in research with political and transformative agendas, including feminist research on gender categories, LGBT issues, women's work, and research ethics. In particular, the tools of CA facilitate analysis of the 'micro-inequalities' of everyday social life (Haslett and Lipman, 1997), offering a powerful and rigorous method for examining how mundane, routine, forms of oppression (e.g. sexism, heterosexism, racism, ageism) are woven into the fabric of social interaction. Our own work uses CA to examine the operation of social norms and the reproduction of culture, especially related to genders and sexualities (e.g. Kitzinger, 2000; Wilkinson and Kitzinger, 2007a).

Conversation analysis - the study of talk-in-interaction - is a theoretically and methodologically distinctive approach to understanding the social world. It is interdisciplinary in nature, spanning, in particular, the disciplines of psychology, sociology, linguistics and communication studies (see Wilkinson and Kitzinger, 2007b for an introduction for psychologists). It was first developed in the USA in the late 1960s and early 1970s by Harvey Sacks, Emanuel Schegloff, and Gail Jefferson (see Lerner, 2004). Harvey Sacks was tragically killed in a road accident in 1975 , leaving much of the subsequent development of the field to his collaborators, colleagues and students. His 
lectures, transcribed and edited by Jefferson, and with an extensive introduction by Schegloff, were published some 20 years after his death (Sacks, 1995).

CA's intellectual roots lie in the broad sociological tradition of ethnomethodology, and in the work of Erving Goffman and Harold Garfinkel, in particular. Ethnomethodology is concerned with social members' ways of making sense of the everyday social world, and for ethnomethodologists, social phenomena such as power and oppression are primarily accomplishments (Garfinkel, 1967): processes continually created, sustained - and sometimes resisted - through the practices of social members in interaction. CA "describes methods persons use in doing social life" (Sacks, quoted in Psathas, 1995: 53) - talk (as such) is not given any principled primacy. The methodology of CA was shaped by the availability to Sacks (and others) of tape-recorded conversations (initially from a suicide prevention centre), which could be repeatedly inspected, and subsequently transcribed.

CA rests on three key theoretical assumptions: (i) that talk is a form of action; (ii) that action is structurally organized; and (iii) that talk is central to intersubjectivity (Heritage, 1984). Understanding talk as a form of action (CA's first assumption) mandates a focus on what people do with talk, rather than simply on what they say. Conversation analysts study everyday conversational actions (such as complaining, complimenting, disagreeing, inviting, telling, and so on), and also actions that constitute particular institutional contexts (such as second-language teaching, medical diagnosis, or police interrogation). Understanding action as structurally organized (CA's second assumption) leads to technical specifications of the rules and practices that structure talkin-interaction, independent of particular speaker characteristics, and how these constrain 
and enable particular actions. This generates a body of knowledge which describes the basic characteristics of talk-in-interaction. Understanding talk as central to intersubjectivity (CA's third assumption) means that, rather than conceptualising intersubjectivity as an intra-psychic phenomenon, it is seen as depending upon displayed understandings of prior talk. Through producing a turn hearable as an answer, for example, a speaker shows that she has heard the prior turn as a question; or through producing (appropriately-timed) laughter, a speaker shows she has recognized - and appreciated - the punchline of a joke. Such displayed understandings of prior talk are referred to as "participants' orientations".

CA is defined by a cumulative body of empirical research which specifies key interactional phenomena. These interactional phenomena fall into six key areas (or, in Schegloff's (2007a) terminology 'generic orders of organization'). These are: turn-taking (e.g. Sacks, Schegloff and Jefferson, 1974), sequence organization (e.g. Schegloff, 2007a), action-formation (e.g. Schegloff, 1996a), repair (e,g, Schegloff, Jefferson and Sacks, 1977), word-selection (e.g. Schegloff, 1996b) and the overall structural organization of talk (e.g. Schegloff and Sacks, 1973). This reliance on, and contribution to, a set of cumulative body of knowledge about the rules and practices of talk-ininteraction is what most clearly differentiates CA from discourse analysis and discursive psychology, some forms of which are - increasingly - drawing on its discoveries (e.g. Edwards, 1997; Potter, 1996).

In contrast to the self-report or experimentally-generated data typical of much social psychology (or the invented data typical of much linguistics), CA works with actual instances of talk-in-interaction. The analytic procedure depends upon the repeated 
inspection of recorded and transcribed naturalistic data. Transcription - based on a distinctive notation developed by Jefferson (2004) - preserves fine-grained details of talk such as in-breaths, sound stretches and brief pauses (see the transcription key at the end of this article). This is because such fine-grained details are demonstrably oriented to by the participants in the conversation, and systematically affect what they do next in their talk. However, it is the recordings themselves - not transcripts of them - that constitute the primary data of CA. Sound (and sometimes video) files are increasingly being made available on the World Wide Web, giving readers of published work access to the original data. (Whenever a data extract displayed in this article is available to listen to, the URL for the sound file may be found at the top of the data extract.) Video recordings are essential to the study of face-to-face interactions, as they enable the examination of gaze, gesture and other body-behavioural features alongside the talk (e.g. C. Goodwin, 2000). Although new data are continually being collected, several core data sets have been shared within the CA community since the 1970s, and are frequently reanalyzed for new phenomena.

CA has sometimes been characterised by feminist (and other critical) researchers as having too narrow and restrictive a scope for politically-engaged research. Critics of CA have proposed that, because of its attention to the fine detail of talk, independent of speaker characteristics (such as gender), it is not well-suited to the feminist agenda of understanding power and oppression (Billig, 1999; Wetherell, 1998). According to one such critic, CA "limits admissible context so severely that only the most blatant aspects of gendered discursive practice, such as the overt topicalizing of gender in conversation, are likely candidates for Schlegloffian analysis" (Bucholtz, 2003: 52). Another criticizes 
"the rigid assumption that sociality can be represented by textuality" (Hegarty, 2007: 52). $\mathrm{CA}$ is frequently dismissed as jargon-ridden, impenetrable, and - despite its declared focus on participants' orientations - divorced from speakers' own understandings of what is happening in social interaction: "who is aware that a TRP ... is approaching as they speak?" and "who realizes they are producing a dispreferred second or a presequence?", says one feminist linguist (Lakoff, 2003: 168-9). (In fact, as we will show, coconversationalists are very well aware of these features of talk.)

Such critiques incorporate various "misunderstandings or misreadings" of CA (Schegloff, 1999: 559) in relation both to its theoretical assumptions (see Kitzinger, 2000 ) and to its methodology (see Kitzinger, 2007a; Wilkinson and Kitzinger, 2007b). In addition, they fail to acknowledge either the classic feminist work which draws on CA, or the - now substantial - body of contemporary work which does so, some of which explicitly identifies itself as feminist conversation analysis. Classic work includes West and Zimmerman's explorations of interruptions in cross-sex conversation (e.g. West, 1979; Zimmerman and West, 1975) and Goodwin's analyses of girls' talk (e.g. M.H. Goodwin, 1990). In the last six or seven years there has been a dramatic increase in CA and CA-influenced research on gender and sexuality by feminists and other critical researchers: see, for example, Stokoe (2000; 2005); Speer (2005); Tainio (2003); RendleShort (2005); Weatherall (2002); and several contributions to the collections edited by Mcllvenny (2002) and Stokoe and Weatherall (2002) - in addition to our own work, and that of our students, upon which we draw in what follows.

A recent edition of the international journal, Feminism \& Psychology (Volume 17, number 2, May 2007) showcases explicitly feminist conversation analytic work by 
students at the University of York, UK. In interviews about their work (Kitzinger, 2007b), these feminist practitioners of CA provide a powerful counter to the critics quoted above. Merran Toerien describes as “inspiring”, CA's “insistence on studying social life in action and always with a fine-grained sensitivity to the real people involved" (p.139), while Rose Rickford values CA's “enabling us to look at the world through the eyes of our participants, instead of imposing our own vision of the world on them" (p.134). She goes on to say: "For me the most important thing about CA is that it's inherently political. It politicizes the everyday. It completely overturns the notion that politics belongs in a separate space ... I believe that by changing the everyday, we can change the world." (p.134).

In the remainder of this paper, we will illustrate how some of the foundational discoveries of CA have been used in feminist and critical contexts, with a particular focus on (a) turn-taking and turn design; and (b) sequence organization and preference structure. We will end with an examination of conversation analytic contributions to feminist/critical work.

\section{USING TURN-TAKING AND TURN DESIGN}

The analysis of turn-taking and turn-design looks at how people decide when to start and stop talking, and how they pass the conversational floor between them in an orderly way. Sacks, Schegloff and Jefferson's (1974) classic paper on turn-taking presents a model for ensuring that, by and large, people speak one at a time in conversation. Summarized very simply, this model proposes the existence of 'turn-constructional units' (TCUs), which 
can be whole sentences, phrases, or sometimes just single words, but which, in context, are recognizable as potentially constituting a complete turn. Each speaker is initially entitled to just one of these - after which, another speaker has the right (and sometimes the obligation) to speak next. The turn-taking organization is designed to minimize turn size, such that a turn of one (and only one) TCU is the default. Extended turns with lengthy and/or multiple TCUs do not simply happen, they are accomplishments. This has important implications for the analysis of overlapping talk and long turns at talk illustrated below with reference to feminist work which draws, in particular, on CA findings about turn-taking and turn-design.

\section{'Gender and interruption': A feminist project focusing on overlapping talk}

Since Lakoff's (1975) pioneering suggestions about gendered speech differences, a large body of empirical research has compared men's and women's speech across variables such as use of polite forms, expletives, tag questions, topic proffers, self-corrections, and so on (see Aries, 1996 for a review). One of the key differences proposed is the claim that women are disproportionately interrupted by men - and that these interruptions are displays of dominance and control (Zimmerman and West, 1975). The extensive body of research prompted by this claim consists of contradictory and, ultimately, inconclusive findings.

In CA terms, 'interruption' can be understood as what happens when someone violates normative turn-taking practices. In Sacks et al's (1974) model, coconversationalists track the talk in the course of its production - using syntax, prosody and pragmatics as resources - to project when a turn is coming to possible completion. A 
next speaker may legitimately start at a place where a turn is possibly complete (a 'transition relevance place', or TRP). A key CA finding is that a great deal of overlapping talk is caused by next speaker start-up at a place where a turn could have been possibly complete, but - as it turns out - is not. For example (overlapping speech indicated by square brackets, but highlighted in bold typeface for ease of reference):

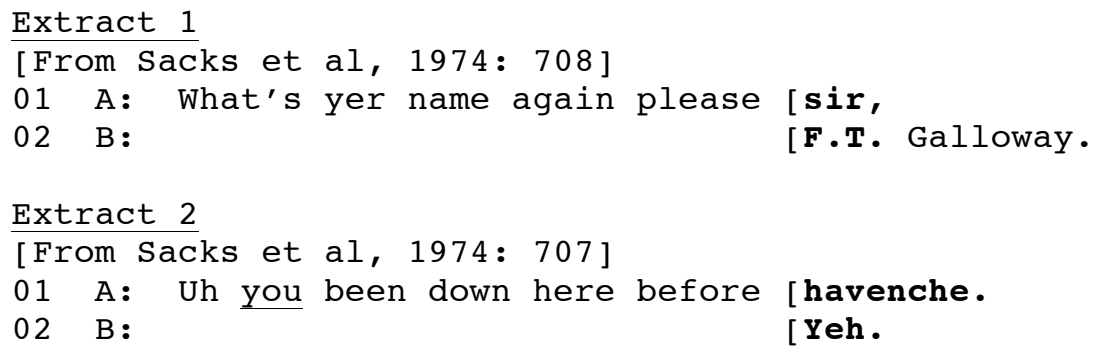

In both instances, Speaker A has produced as part of their turn what the authors term 'optional elements' - the address term 'sir' (Extract 1), the tag question 'haven't you' (Extract 2). In both instances, Speaker B started up at a possible TRP: i.e. a point at which it was projectable that the prior turn would be complete and that their turn would be launched in the clear, without either a gap or an overlap. However, because of the 'optional' element included in the prior turn, this turned out to be a misprojection.

Brief and unproblematic instances of overlap like these are very common in conversation. They are not exercises of power or attempts to dominate the conversation, but, rather, a by-product of the operation of the turn-taking system. Most overlap in conversation, then, is 'accidental' - a product of co-interactants' orientations to turntaking rules and not a flagrant violation of them. Conversation analysts distinguish between overlapping talk (which is simply a description of two or more persons in the same conversation talking concurrently) and interruption (or 'interjacent' overlap, 
Jefferson 1986) - in which the overlapping talk is analysably produced in violation of turn-taking rules.

Kitzinger (2007a) searched the classic CA data sets for instances of overlapping talk (these were pervasive), and determined which of these were also interruptive - i.e. where speaker start-up was not at a possible TRP (these were relatively rare). She found no evidence that men launch interruptive talk more than women, or disproportionately when in interaction with female speakers. Further, when interruptions were launched (whether by men or women, and whether their co-conversationalists were male or female), they were overwhelmingly co-operative, affiliative and helpful, rather than hostile.

Here is an example (from one of the classic data sets, 'NB'). Emma has phoned to speak to her friend Lottie, but it is Lottie's husband (Earl) who has answered and it is apparent to Emma - as she later says - that Lottie and Earl 'have company'. When Earl offers to call his wife to the phone ('you want to talk to Lottie?', line 2), Emma - who clearly does want to talk to Lottie (as it turns out she has exciting news to tell) - demurs. After a short silence (line 3) and turn-initial delay (the 'uh' in line 4) she confirms that she did want to talk to Lottie, but immediately follows this with a display of her realisation that Lottie is 'busy' (i.e. occupied with the couple's guests) and launches a counter-offer - she'll call back later (line 4). This is the turn that is interrupted by Earl, and Emma doesn't complete it.

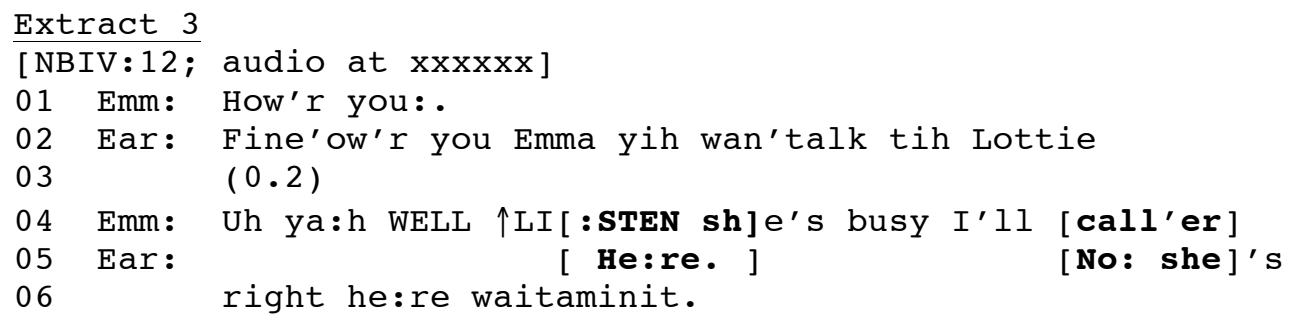




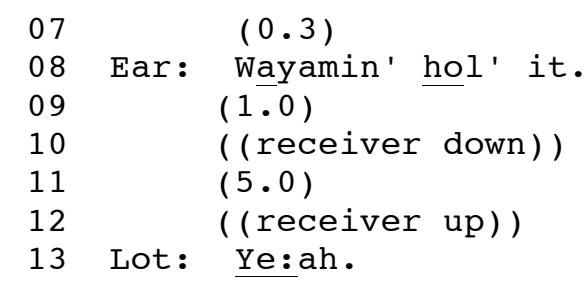

Earl first interrupts Emma after she has confirmed that she wants to talk to Lottie, but has also indicated her awareness of some problem with this (with 'WELL', line 4). Earl's interruptive 'here' (line 5) is a first move to hand the phone over to his wife. Finding himself to have interrupted, he waits until Emma has - projectably - finished her turn (with 'Well listen she's busy', line 4), and then - at this possible TRP - he rejects Emma's implication that Lottie might not be available to speak to her (with 'No', line 5). However, it turns out he has misprojected the end of Emma's turn, and he finds himself again in overlap with Emma, who is now offering to call back later. Emma abandons her TCU (after 'I'll call her' - presumably headed for something like 'I'll call her back later/tomorrow/some other time') and Earl persists with his TCU, countering Emma's 'she's busy' with his offer 'she's right here' (lines 5-6). He directs her to 'wait a minute' (lines 6 and 8) and to 'hold it' (line 8). Seven seconds later, Lottie comes to the phone. Emma and Lottie get to talk to each other in part because Earl interrupted Emma, who was proposing to abandon the current attempt at conversation.

In this extract, then, a man (Earl) interrupts a woman (Emma) at a point where she cannot possibly have finished speaking. However, this is not a display of male dominance and control - rather, from Emma's point of view, this interruption was implementing a helpful action, enabling her to speak to her friend right away. The vast majority of interruptions in the data examined by Kitzinger (2007a) were of this type. Here, using CA specifications of turn-taking and turn design - the difference between 
interruptive and non-interruptive overlaps, and the actions implemented through interruption - provides a valuable way of interrogating claims about gendered speech differences.

Other feminist/critical projects that draw, in particular, on the CA domain of turntaking and turn-design include an examination of the specialised turn-taking practices in a beauty salon, where the beauty therapist has to manage both task-directed talk and topic talk ('chatting') with her client (Toerien and Kitzinger, 2007a,b); and a study of how people typically 'come out' to others as lesbian or gay - by embedding information about their sexuality in the middle of a long turn (Kitzinger, 2000).

\section{USING SEQUENCE ORGANIZATION AND PREFERENCE STRUCTURE}

We turn now to feminist/critical projects drawing, in particular, on a second major area of CA: sequence organization and preference structure. Sequences are successive turns at talk through which some activity (e.g. inviting, complaining, apologising) gets accomplished. The most basic type of sequence involves two (adjacent) turns at talk by different speakers, the first constituting an initiating action, and the second an action responsive to it (Schegloff, 2007a). Most initiating actions can be followed by a range of sequentially-relevant (i.e. appropriately 'fitted') next actions: for example, an invitation can be followed by an acceptance or a refusal; a request by a granting or a denying; a proposal by an acquiescence or a rejection, and so on. But these alternative responsive actions are not equivalent (Sacks, 1987/1973). In CA terminology, an acceptance of an invitation, a granting of a request or an acquiescence with a proposal are preferred next 
actions; a refusal of an invitation, a denying of a request or a rejection of a proposal are dispreferred. 'Preference' is a structural concept, rather than a psychological one: i.e. the fact that an invitation 'prefers' an acceptance is independent of the personal preference of the recipient of that invitation. (Most of us will have had the experience of accepting an invitation that we would - personally - have preferred to have refused.)

Preferred and dispreferred responses run off very differently (Pomerantz, 1984; Sacks, 1987/1973). Preferred responses are characteristically offered without delay, and are clear and direct. Here is an example of a recipient accepting an invitation:

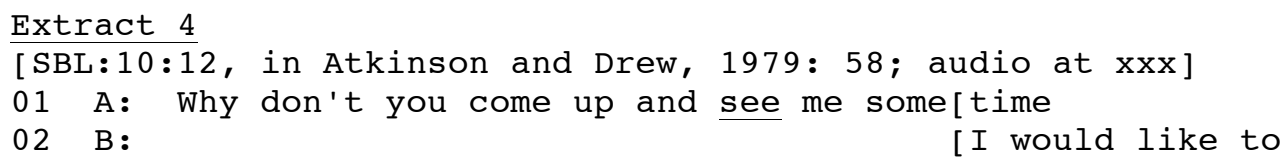

Dispreferred responses, by contrast, are often delayed, hedged, and accompanied by accounts, excuses or justifications. Here is an example of a recipient refusing an invitation:

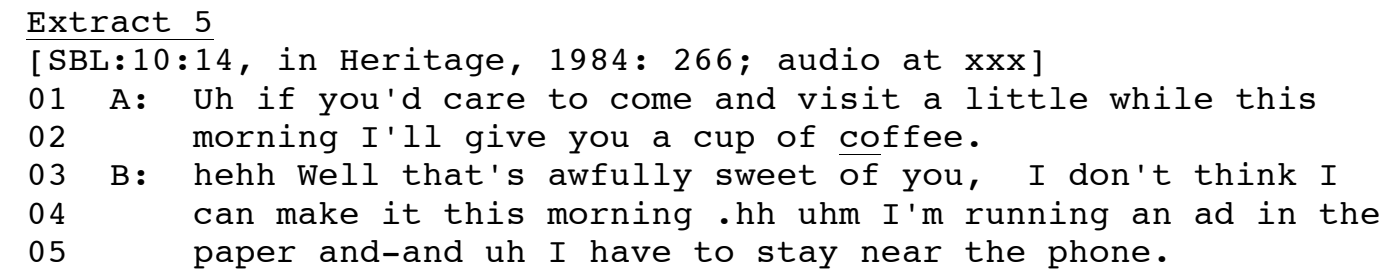

There is a delay (a filled silence: 'hehh') and a hedge ('Well') before the refusal; it is softened by a palliative (the compliment 'that's awfully sweet of you'); and explained by reference to a prior commitment ('I have to stay near the phone'). We can also note that the account proposes an inability - rather than an unwillingness - to accept the invitation (Drew, 1984); and that Speaker B does not actually use the word 'no'. Both of these features are typical of refusals (Davidson, 1984; Levinson, 1983) - and relevant for the feminist project we outline below. 
'Just say no’: A feminist project focusing on dispreferred responses

One of our earliest feminist CA projects was on young women's talk about sexual refusal (Kitzinger and Frith, 1999). There is a substantial literature indicating that young women report difficulty in refusing unwanted (hetero)sex. This literature proposes that many instances of date rape are the result of women not communicating clearly to men the fact that they do not want sex (e.g. Warzak and Page, 1990). This, in turn, has led to the development of so-called 'refusal skills training': a variety of date rape prevention, assertiveness training and social skills programmes and manuals, which teach women to be assertive in refusing sex, to 'just say no' clearly, directly and unapologetically (e.g. Kidder, Boell and Moyer, 1983).

However, CA analyses of how refusals are actually done shows us something very different. We have seen above that acceptances and refusals follow very different patterns: acceptances do indeed often involve 'just saying yes', but refusals very rarely involve 'just saying no'. If young women find it difficult to give immediate, clear, direct 'no's in sexual situations, that might be because that is not how refusals are normatively done. Refusal skills training manuals seem to be offering advice that does not capture social reality.

Further, young women themselves are able to articulate this. Although we don't have (the ideal) data in which young women are actually doing sexual refusals (see Tainio, 2003 for an example of this), we do have data in which they talk about doing such refusals - and their discussions embody a lay version of CA discoveries (of course, they don't use terminology such as 'dispreferred' or 'palliative'). When asked why they 
don't 'just say no', young women explain that that would feel 'rude' or 'foolish', and they describe the 'best' explanations or excuses as those which assert their inability, rather than their unwillingness to engage in sex (illness, menstruation, a parent's imminent arrival home). They say it is a good idea to qualify or mitigate refusals ('I'm not ready yet'), and to soften the blow with - what CA calls - palliatives ('well it's very flattering of you to ask). They know very well how refusals are normatively done - as indeed, do young men (O’Byrne et al, 2006) - and are able to use this knowledge to criticize and resist the advice to 'just say no'.

On the basis of this analysis, we suggest that the insistence of date rape educators on the importance of 'just saying no' is counter-productive in that it requires women to engage in conversationally abnormal actions. CA shows us that refusals are not typically done in such a direct and unvarnished way; and that it is not necessary to say the word 'no' in order to be heard as doing a refusal. The advice to 'just say no' also allows rapists to persist in their claim that if a woman hasn't actually said no, then she hasn't actually refused to have sex. Using CA specifications of sequence organization and preference structure, examination of how refusals are normatively done shows us the mundane, everyday operation of the practices of oppression - and resistance.

Other feminist/critical projects that draw, in particular, on the CA domain of sequence organization and preference structure include an analysis of women's reports of abuse made at a women's police station in Brazil (Guimaraes, 2007); and a study examining the effects of Alzheimer's disease on communication between family members, particularly mothers and daughters (Kitzinger and Jones, 2007). 


\section{CONTRIBUTIONS TO FEMINIST/CRITICAL WORK}

In this final section, we will look at some key areas of feminist and critical work where the analytic techniques and key empirical findings of conversation analysis have proved particularly fruitful: categories and gender; LGBT issues; women's labour; and the ethics, politics and design of the research process. We hope thereby further to underscore the value of CA for political and transformative research, particularly research which seeks to understand how oppression operates in everyday social life.

\section{Categories and gender}

One central concern of second wave feminism was 'man made' language, and the ways this is used by men in exercising power over women (e.g. Spender, 1980). This, in turn, generated a substantial body of research on gender and language (to which we have already referred), much of it examining gendered speech differences or communication styles. Contemporary gender and language research is more diverse, and one of its most vibrant areas is the application of CA work on person reference and membership categorization (Schegloff, 2007b) to study gender categories. Feminist researchers have considered the selection of gendered category terms from amongst possible alternatives (e.g. 'girl' or 'woman', Stokoe, 2007); and the ways in which particular gendered category terms are bound to particular attributes or occupations (e.g. 'female-secretary', Stokoe, 2006).

Research in this area has looked, in particular, at the actions which referring to someone (occasionally, oneself: West and Fenstermaker, 2002) as a member of a 
particular gender category may be designed to do. In one study - a discussion between women with breast cancer - a women accounts for her husband's problems in coming to terms with her post-mastectomy body by positioning him within the category 'men'. He is exonerated from individual culpability for his difficulties because it is a cultural commonplace that - as most of the participants in the discussion agree - 'all men like boobs' (Wilkinson and Kitzinger, 2003). In another - a call to a helpline for women with symphysis pubis disorder, in which the pregnant caller has reported being 'a bit scared' about her forthcoming labour - the call-taker suggests that she encourage her partner to accompany her to a forthcoming medical consultation. The call-taker justifies this advice through a claim that having a 'bloke' in the room 'does make a difference' (thereby categorizing the caller's partner as a representative of the category 'bloke'). The claim relies on cultural understandings of the characteristics typical of 'blokes', and in not specifying these - rather, simply invoking the category - it is rendered difficult to challenge (Kitzinger and Rickford, 2007). For further studies of this type, see Stockill and Kitzinger (2007); Wilkinson and Kitzinger (2007b,c). Finally, feminist conversation analysts have problematised the assumption that gendered category terms - such as ‘woman' - are always relevantly gendered (Kitzinger, 2007c).

\section{LGBT issues}

A second area of feminist/critical work where CA is proving particularly useful is lesbian, gay, bisexual and transgender (LGBT) issues. One particular focus - as in the field of LGBT studies more generally (e.g. Meyer, 2003) - is research on 'coming out'. Building on Kitzinger's (2000) study - referred to above - of 'mundane' comings-out 
based on turn-taking phenomena, more recent work has examined how comings-out also rely on phenomena drawn from the CA domain of repair and error correction (Land and Kitzinger, 2005). It has also examined an instance of 'not coming out', when - in sequence organization terms - an appropriate interactional 'slot' in which to do so (responding to a question about marital status) has been created (Wilkinson and Kitzinger, 2003). Victoria Land's data set - based on more than 150 telephone calls to and from 5 lesbian households - is an important addition to the classic data sets upon which CA work very commonly draws, which overwhelmingly represent the talk of heterosexuals (Kitzinger, 2005a). Land's doctoral research also looks more broadly at talk about lesbian and gay relationships (Land and Kitzinger, 2007a), particularly in the light of marriage and civil partnership legislation (Land and Kitzinger, 2007b).

Another important strand of enquiry here is the way in which gendered norms and heteronormativity are continually reflected and reproduced everyday social life. Contexts include the psychiatric assessment of transsexual patients in a gender identity clinic (Speer, 2007; Speer and Green, 2007); and out-of-hours calls to a doctor's surgery (Kitzinger, 2005b). In trying to persuade the doctor to make a home visit, callers routinely select person reference terms from the set representing the heterosexual nuclear family (particularly 'husband' and 'wife') - terms which are not generally available to people in same-sex relationships. Through practices such as these, we can see the reflection and reproduction of a gendered and heteronormative culture.

\section{Women's labour}


Another key area of feminist research has been the gendered division of labour, with a key focus being women's underpaid - and often unacknowledged - labour inside and outside the home (Tancred, 1995). Here, too, CA studies are making major contributions. One looks at how in the poorly paid, highly gendered world of the beauty salon, a beauty therapist manages the 'emotional labour' (Hochschild, 1983) of personalizing a routine encounter by engaging in topic talk with her client; and at the same time, navigates between topic talk and task-directed talk in such as way as to produce a 'smooth' interaction (Toerien and Kitzinger, 2007a,b). Another (also referred to earlier) considers the - often invisible - dimensions of relational work that women do as part of caring for their families, in examining the effects of Alzheimer's disease on mother-daughter interaction (Kitzinger and Jones, 2007).

There are now a number of feminist CA studies of women's work in relation to childbirth - focusing, in particular - on the operation of birth-related helplines (typically staffed by women). Helpline interaction more generally is an important - and growing area of applied CA research (Edwards, 2007). Rebecca Shaw's doctoral research analysed calls to a helpline for women facing difficulties in arranging a home birth, including problem-presentation and advice-giving (Shaw and Kitzinger, 2007a), and issues arising in repeat calls (Shaw and Kitzinger, 2007b). Other helplines currently under study are Pelvic Partnership, for women with symphysis pubis disorder (Kitzinger and Rickford, 2007) - from which the 'bloke' example above is taken; and the Birth Crisis Network, for women experiencing trauma or distress following childbirth. Selected extracts of Birth Crisis calls which highlight particular interactional phenomena (e.g. the appropriate use of story prompts, continuers, or silence) are being used as a tool 
to train midwives and other health caregivers in how to provide more effective support to women in crisis after childbirth (Kitzinger and Kitzinger, 2007). For video-based studies of childbirth interactions which draw on CA, see also Bergstrom et al $(1992,1997)$.

\section{Research ethics, politics and design}

Feminist and other critical researchers typically consider the ethics and politics of research, including their relationship with research participants, and are often concerned to avoid reproducing gendered (and other) power relations in their own projects (Oakley, 1981). Here, too, there is a fruitful engagement between feminist/critical concerns and conversation analysis. Estefania Guimaraes (2007) offers a self-reflective conversation analysis of her developing research practice in studying women's reports of abuse to police and other professionals in Brazil. She shows how, in recording these reports (at a women's police station and a care centre for abused women) she moved from attempting to collect 'uncontaminated' data to trying to do whatever she could for the complainant, right there and then, despite its consequences for the recorded interaction. A similar kind of reflection based on the analysis of recorded interaction is offered by Braun (2000), who examines her own collusion with the heterosexist assumptions displayed by research participants.

One final - related - consideration is the design of research, with feminist/critical researchers taking seriously the responsibility of how best to represent the realities of their research participants' lives (Maynard and Purvis, 1994). CA, as we have seen, offers a fine-grained sensitivity to participants' own understandings of the world (see Wilkinson, 2006 for its advantages over other qualitative approaches to data analysis). In 
addition, the techniques of CA are increasingly being used in multi-method research, alongside other methods of data collection (such as questionnaires: Toerien and Wilkinson, 2004), and/or other methods of data analysis (such as thematic analysis: Shaw and Kitzinger, 2005). In this way, it is possible - within a single research project - both to pay close and detailed attention to what research participants say, and also to take a 'broader brush' approach to issues of social and political concern.

In sum, then, we have shown that - despite some critics' insistence that CA is not well-suited to the goals of feminist and critical researchers - it is proving to be a valuable tool for politically-engaged research and social critique. CA offers a powerful, empirically rigorous, method for studying the ways in which the practices of talk-ininteraction contribute to the mundane, routine oppressions which are threaded through everyday social life and culture. 


\section{REFERENCES}

Aries, E. (1996). Men and Women in Interaction: Reconsidering the Difference. New York: Oxford University Press.

Bergstrom, L., Roberts, J., Skillman, L. and Seidel, J. (1992). "You'll feel me touching you, sweetie": Vaginal examinations during the second stage of labor. Birth, 19: 1018.

Bergstrom, L., Seidel, J., Skillman-Hull, L. and Roberts, J. (1997). "I gotta push. Please let me push!" Social interactions during the change from first to second stage labor. Birth, 24: 173-180.

Billig, M. (1999). Whose terms? Whose ordinariness? Rhetoric and ideology in conversation analysis. Discourse \& Society, 10(4): 543-558.

Braun, V. (2000). Heterosexism in focus group research: Collusion and challenge. Feminism \& Psychology, 10(1): 133-140.

Bucholtz, M. (2003). Theories of discourse as theories of gender. In J. Holmes and M. Meyerhoff (eds), The Handbook of Language and Gender (pp. 43-68). Oxford: Blackwell.

Davidson, J. (1984). Subsequent versions of invitations, offers, requests and proposals dealing with potential or actual rejection. In J.M. Atkinson and J. Heritage (eds), Structures of Social Action: Studies in Conversation Analysis (pp.102-128). Cambridge: Cambridge University Press. 
Drew, P. (1984). Speakers' reportings in invitation sequences. In J.M. Atkinson and J. Heritage (Eds), Structures of Social Action: Studies in Conversation Analysis (pp. 152-164). Cambridge: Cambridge University Press.

Edwards, D. (1997). Discourse and Cognition. London: Sage.

Edwards, D. (Ed.) (2007). Calling for Help. Special issue of Research on Language and Social Interaction, 40(1).

Garfinkel, H. (1967). Studies in Ethnomethodology. Englewood Cliffs, NJ: Prentice-Hall. Goodwin, C. (2000). Action and embodiment within situated human interaction. Journal of Pragmatics, 32: 1489-1522.

Goodwin, M.H. (1990). He-Said-She-Said: Talk as Social Organization Among Black Children. Bloomington, IA: Indiana University Press.

Guimaraes, E. (2007). Feminist research practice: Using conversation analysis to explore the researcher's interaction with participants. Feminism \& Psychology, 17(2): $149-161$.

Haslett, B.B. and Lipman, S. (1997). Micro-inequalities: Up close and personal. In N.V. Benokraitis (ed.), Subtle Sexism: Current Practice and Prospects for Change (pp.34-51). Thousand Oaks, CA: Sage.

Hegarty, P. (2007). What comes after discourse analysis for LGBTQ psychology? In V. Clarke and E. Peel (eds), Out in Psychology: Lesbian, Gay, Bisexual, Trans and Queer Perspectives (pp. 41-57). London: Wiley.

Heritage, J. (1984). Garfinkel and Ethnomethodology. Cambridge: Polity Press.

Hoshschild, A. (1983). The Managed Heart: Commercialization of Human Feeling. Berkeley, CA: University of California Press. 
Jefferson, G. (2004). Glossary of transcript symbols with an introduction. In G.H. Lerner (ed.), Conversation Analysis: Studies from the First Generation (pp. 13-31). Amsterdam: John Benjamins.

Kidder, L.H., Boell, J.L. and Moyer, M.M. (1983). Rights consciousness and victimization prevention: Personal defence and assertiveness training. Journal of Social Issues, 39: 155-170.

Kitzinger, C. (2000). Doing feminist conversation analysis. Feminism \& Psychology, 10(2): 163-193.

Kitzinger, C. (2005a). Speaking as a heterosexual: (How) does sexuality matter for talkin-interaction? Research on Language and Social Interaction, 38(3): 221-265.

Kitzinger, C. (2005b). Heteronormativity in action: Reproducing the heterosexual nuclear family in 'after hours' medical calls. Social Problems, 52(4): 477-498.

Kitzinger, C. (2007a). Conversation analysis: technical matters for gender research. In L. Litosseliti, H. Saunston, K. Segall and J. Sunderland, (eds), Gender and Language: Theoretical and Methodological Approaches. London: Palgrave Macmillan.

Kitzinger, C. (2007b). The promise of conversation analysis for feminist research. Introduction to Special Feature on 'Feminist conversation analysis: Research by students at the University of York, UK'. Feminism \& Psychology, 17(2): 133148.

Kitzinger, C. (2007c). Is ‘woman’ always relevantly gendered? Gender and Language, 1(1): 39-49. 
Kitzinger, C. and Frith, H. (1999). Just say no? The use of conversation analysis in developing a feminist perspective on sexual refusal. Discourse \& Society, 10(3): 293-316.

Kitzinger, C. and Jones, D. (2007). When May calls home: The opening moments of family telephone conversations with an Alzheimer's patient. Feminism \& Psychology, 17(2): 184-202.

Kitzinger, C. and Kitzinger, S. (2007). Birth trauma: Talking with women and the value of conversation analysis. British Journal of Midwifery, 15(5): xxx-xxx.

Kitzinger, C. and Rickford, R. (2007). Becoming a 'bloke': The construction of gender in interaction. Feminism \& Psychology, 17(2): 214-223.

Lakoff, R. (1975). Language and Woman's Place. New York: Harper and Row.

Lakoff, R. (2003). Language, gender and politics: Putting 'women' and 'power' in the same sentence. In J. Holmes and M. Meyerhoff (eds), The Handbook of Language and Gender (pp. 161-178). Oxford: Blackwell.

Land, V., \& Kitzinger, C. (2005). Speaking as a lesbian: Correcting the heterosexist presumption. Research on Language and Social Interaction, 38.

Land, V. and Kitzinger, C. (2007a). Closet talk: The contemporary relevance of the closet in lesbian and gay interaction. In V. Clarke and E. Peel (eds), Out in Psychology: Lesbian, Gay, Bisexual, Trans and Queer Perspectives (pp. 148-171). London: Wiley.

Land, V. and Kitzinger, C. (2007b). Contesting same-sex marriage in talk-in-interaction. Feminism \& Psychology, 17(2): 173-183. 
Lerner, G.H. (2004). Conversation Analysis: Studies from the First Generation. Amsterdam: John Benjamins.

Levinson, S.C. (1983). Pragmatics. Cambridge: Cambridge University Press.

Maynard, M. and Purvis, J. (1994). Doing feminist research. In M. Maynard and J. Purvis (eds), ResearchingWomen's Lives from a Feminist Perspective (pp.1-9). London: Taylor and Francis.

McIlvenny, P. (ed.) (2002). Talking Gender and Sexuality. Amsterdam: John Benjamins. Meyer, I.H. (2003). Prejudice, social stress and mental health in lesbian, gay and bisexual populations: Conceptual issues and research evidence. Psychological Bulletin, 129(5): 674-697.

Oakley, A. (1981). Interviewing women: a contradiction in terms. In H. Roberts (ed.), Doing Feminist Research (pp. 30-61). London: Routledge and Kegan Paul.

O'Byrne, R., Rapley, M. and Hansen, S. (2006). “You couldn't say 'no', could you?”: Young men's understandings of sexual refusal. Feminism \& Psychology, 16(2): 133-154.

Pomerantz, A. (1984). Agreeing and disagreeing with assessments: Some features of preferred/dispreferred turn shapes. In J.M. Atkinson and J. Heritage (eds), Structures of Social Action: Studies in Conversation Analysis (pp. 57-101). Cambridge: Cambridge University Press.

Potter, J. (1996). Representing Reality. London: Sage. Psathas, G. (Ed.) (1995). Conversation Analysis: The Study of Talk-in-Interaction. London: Sage. 
Rendle-Short, J. (2005). "I've got a paper-shuffler for a husband": Indexing sexuality on talk-back radio. Discourse \& Society, 16(4): 561-578.

Sacks, H. (1987/1993). On the preferences for agreement and contiguity in sequences in conversation. In G. Button and J.R.E. Lee (eds), Talk and Social Organisation (pp. 54-69). Cleveland: Multilingual Matters.

Sacks, H. (1995). Lectures on Conversation, Volumes 1 and 2. Oxford: Blackwell.

Sacks, H., Schegloff, E.A. and Jefferson, G. (1974). A simplest systematics for the organization of turn-taking for conversation. Language, 50(4): 696-735.

Schegloff, E.A. (1996a). Confirming allusions: Toward an empirical account of action. American Journal of Sociology, 102(1): 161-216.

Schegloff, E. A. (1996b). Some practices for referring to persons in talk-in-interaction: A partial sketch of a systematics. In B. Fox (ed.), Studies in Anaphora (pp. 437485). Amsterdam: John Benjamins.

Schegloff, E.A. (1999). 'Schegloff's texts' as 'Billig's data': A critical reply. Discourse \& Society, 10(4): 558-572.

Schegloff, E.A. (2007a). Sequence Organization in Interaction: A Primer in Conversation Analysis, Volume 1. Cambridge: Cambridge University Press.

Schegloff, E.A. (2007b). Categories in action: Person reference and membership categorization. Discourse Studies, 9(4): xxx-Xxx.

Schegloff, E. A., Jefferson, G., \& Sacks, H. (1977). The preference for self-correction in the organization of repair in conversation. Language, 53, 361-382.

Schegloff, E.A. and Sacks, H. (1973). Opening up closings. Semiotica, 8: 289-327. 
Shaw, R. and Kitzinger, C. (2005). Calls to a home birth helpline: Empowerment in childbirth. Social Science \& Medicine, 61: 2374-2383.

Shaw, R. and Kitzinger, C. (2007a). Problem presentation and advice-giving on a home birth helpline. Feminism \& Psychology, 17(2): 203-213.

Shaw, R. and Kitzinger, C. (2007b). Memory in interaction: An analysis of repeat calls to a Home Birth helpline. Research on Language and Social Interaction, 40(1): $\mathrm{xxX}-\mathrm{XxX}$.

Speer, S.A. (2005). Gender Talk: Feminism, Discourse and Conversation Analysis. London: Routledge.

Speer, S.A. (2007). The form and function of hypothetical questions in the Gender Identity Clinic. In A. Freed and S. Erlich (eds), Why Do You Ask? The Function of Questions in Institutional Discourse. Oxford: Oxford University Press.

Speer, S.A. and Green, R. (2007). On passing: The interactional organization of appearance attributions in the psychiatric assessment of transsexual patients. In V. Clarke and E. Peel (eds), Out in Psychology: Lesbian, Gay, Bisexual, Trans and Queer Perspectives (pp. 335-368). London: Wiley.

Spender, D. (1980). Man Made Language. London: Routledge and Kegan Paul.

Stockill, C. and Kitzinger, C. (2007). Gendered 'people': How linguistically nongendered terms can have gendered interactional relevance. Feminism \& Psychology, 17(2): 224-236.

Stokoe, E. (2000). Toward a conversation anaytic approach to gender and discourse. Feminism \& Psychology, 10(4): 552-63. 
Stokoe, E. (2005). Analysing gender and language. Journal of Sociolinguistics, 9(1): 118133.

Stokoe, E. (2006). On ethnomethodology, feminism, and the analysis of categorical reference to gender in talk-in-interaction. The Sociological Review, 54(3): 467494.

Stokoe, E. (2007). Categories, actions and sequences: Formulating gender in talk-ininteraction. In L. Litosseliti, H. Saunston, K. Segall and J. Sunderland, (eds), Gender and Language: Theoretical and Methodological Approaches. London: Palgrave Macmillan.

Stokoe, E. and Weatherall, A. (Eds) (2002). Gender, language, conversation analysis and feminism. Special issue of Discourse \& Society, 13(6).

Tainio, L. (2003). 'When shall we go for a ride?' A case of the sexual harassment of a young girl. Discourse \& Society, 14(2): 173-190.

Tancred, P. (1995). Women's work: a challenge to the sociology of work. Gender, Work and Organization, 2(1): 11-20.

Toerien, M. and Kitzinger, C. (2007a). Emotional labour in the beauty salon: Turn-design of task-directed talk. Feminism \& Psychology, 17(2): 162-172.

Toerien, M. and Kitzinger, C. (2007b). Emotional labour in action: navigating multiple involvements in the beauty salon. Sociology, $\mathrm{xxx}-\mathrm{xxx}$.

Toerien, M. and Wilkinson, S. (2004). Exploring the depilation norm: A qualitative questionnaire study of women's body hair removal. Qualitative Research in Psychology, 1: 69-92. 
Warzak, W.J. and Page, T.J. (1990). Teaching refusal skills to sexually active adolescents. Journal of Behavioral Therapy and Experimental Psychiatry, 21: $133-9$.

Weatherall, A. (2002). Gender, Language and Discourse. London: Routledge.

West, C. (1979). Against our will: Male interruptions of females in cross-sex conversations. In J. Orasanu, M.K. Slater and L.L. Adler (Eds), Language, Sex and Gender. Annals of the New York Academy of Sciences, 327: 81-97. New York: New York Academy of Sciences.

West, C. and Fenstermaker, S. (2002). Accountability and affirmative action: The accomplishment of gender, race and class in a University of California Board of Regents Meeting. In S. Fenstermaker and C. West (eds), Doing Gender, Doing Difference (pp. 141-168). New York: Routledge.

Wetherell, M. (1998). Positioning and interpretative repertoires: Conversation analysis and post-structuralism in dialogue. Discourse \& Society, 9(3): 387-412.

Wilkinson, S. (2006). Analysing interaction in focus groups. In P. Drew, G. Raymond and D. Weinberg (eds), Talk and Interaction in Social Research Methods (pp. 50620. London: Sage .

Wilkinson, S., \& Kitzinger, C. (2003). Constructing identities: A feminist conversation analytic approach to positioning in action. In R. Harré \& F. Moghaddam (eds), The Self and Others: Positioning Individuals and Groups in Personal, Political, and Cultural Contexts (pp. 157-180). Westport, CT: Praeger. 
Wilkinson, S. and Kitzinger, C. (2007a). Conversation analysis, gender and sexuality. In A. Weatherall, B. Watson and C. Gallois (eds), Language, Discourse and Social Psychology (pp. 206-230). London: Palgrave Macmillan.

Wilkinson, S. and Kitzinger, C. (2007b). Conversation analysis. In C. Willig and W. Stainton Rogers (eds), The Handbook of Qualitative Methods in Psychology. London: Sage.

Wilkinson, S. and Kitzinger, C. (2007c). The strategic deployment of categories in action. Are husbands men? In G. Raymond, G.H. Lerner and J. Heritage (eds), Enabling Human Conduct: Naturalistic Studies of Talk-in-Interaction in Honor of Emanuel A. Schegloff. Amsterdam: John Benjamins.

Zimmerman, D.H. and West, C. (1975). Sex roles, interruptions and silences in conversation. In B. Thorne and N. Henley (Eds), Language and Sex: Difference and Dominance. Rowley, MA: Newbury House. 


\section{TABLE 1: TRANSCRIPTION KEY FOR DATA EXTRACTS}

\begin{tabular}{|c|c|c|}
\hline ] & square brackets & overlapping talk \\
\hline (0.5) & time in round brackets & $\begin{array}{l}\text { intervals within or between talk } \\
\text { (measured in tenths of a second) }\end{array}$ \\
\hline$:::$ & colons & $\begin{array}{l}\text { extension of preceding sound (the more } \\
\text { colons, the greater the extension) }\end{array}$ \\
\hline . & period & $\begin{array}{l}\text { closing intonation (not necessarily the } \\
\text { end of a sentence) }\end{array}$ \\
\hline , & comma & $\begin{array}{l}\text { continuing intonation (not necessarily } \\
\text { between clauses of sentences) }\end{array}$ \\
\hline here & underlining & emphasis \\
\hline HERE & capitals & loud, relative to surrounding talk \\
\hline .hhh & & $\begin{array}{l}\text { audible inbreath (no. of 'h's indicates } \\
\text { length) }\end{array}$ \\
\hline$\uparrow$ & upward arrow & shift into especially high pitch \\
\hline ((noise) $)$ & $\begin{array}{l}\text { word(s) in double round } \\
\text { brackets }\end{array}$ & note or comment by transcriber \\
\hline
\end{tabular}




\section{SHORT BIOGRAPHIES}

\section{SUE WILKINSON:}

Sue Wilkinson is Professor of Feminist and Health Studies in the Department of Social Sciences, Loughborough University, UK. She was formerly the Ruth Wynn Woodward Endowed Professor of Women's Studies at Simon Fraser University, British Columbia, Canada. She is the Founding Editor of the international journal, Feminism \& Psychology (Sage Publications) and has published widely in the areas of gender, sexuality, health and qualitative methods. Her books include Feminist Social Psychologies (Open University Press), Feminism \& Discourse, Heterosexuality and Representing the Other (all Sage Publications). She is co-founder, with Celia Kitzinger, of Equal Marriage Rights, an organisation campaigning for equal access to marriage for same-sex couples. Her current research interests include the social construction of marriage and partnership; mundane oppression; the conversation analytic phenomena of reaction tokens and repair; and the use of conversation analysis to study interaction in support groups and on helplines. She is currently editing a book on conversation analytic studies of healthcare interactions. She is a Chartered Psychologist and has degrees from Leicester University (BSc Psychology) and Loughborough University (PhD Social Psychology). 


\section{CELIA KITZINGER:}

Celia Kitzinger is Professor of Conversation Analysis, Gender and Sexuality in the Department of Sociology, University of York, UK. She has been a Visiting Professor at the University of California, Los Angeles, the University of Auckland and the University of British Columbia. She has published nine books and more than a hundred articles on lesbian and gay issues, feminism and conversation analysis. Her books include The Social Construction of Lesbianism (Sage), Changing Our Minds (New York University Press) and Lesbian and Gay Psychology (Blackwell). She is co-founder, with Sue Wilkinson, of Equal Marriage Rights, an organisation campaigning for equal access to marriage for same-sex couples. Her current research interests include the social construction of marriage and partnership; mundane oppression; the conversation analytic phenomena of self-reference and offering/requesting; and conversation analytic studies of women in trauma after childbirth. She runs short courses in conversation analysis; and is currently writing a book on feminist conversation analysis, as well as using conversation analysis in training midwives and other healthcare professions who interact with women in distress. She is a Chartered Psychologist and has degrees from the Universities of Oxford (MA Experimental Psychology) and Reading (PhD Psychology). 